\title{
Phytochemical Screening and Antimicrobial Activity of Artocarpus heterophyllus and Artocarpus altilis Leaf and Stem Bark Extracts
}

\author{
P. Sivagnanasundaram and K. O. L. C. Karunanayake* \\ Department of Botany, The Open University of Sri Lanka
}

\section{Abstract}

Increasing drug resistance of pathogens and negative consequences of antibiotic usage has led to the search for alternative medicines from nature. Many plants have been exploited to cure infectious diseases from time immemorial. The present investigation evaluated the antimicrobial and phytochemical properties of Artocarpus heterophyllus i.e. Jack fruit (Kos in Sinhala) and Artocarpus altilis i.e. Bread fruit (Dhel in Sinhala) leaf and stem bark extracts. Hexane, dichloromethane and ethanol were used as extraction solvents and test organisms were Escherichia coli, Micrococcus luteus, Aspergillus niger and Trichoderma sp. A disc diffusion test was adopted to test the susceptibility of the selected microbes to the extracts while Minimum inhibitory concentration (MIC) was determined using serial dilution of extracts. Phytochemical screening was carried out by specific chemical identification tests. Bioassay data were statistically analyzed using two-way ANOVA (SPSS 20 at 95\% confidence level). Ethanolic stem bark extracts $(30 \mathrm{mg} / \mathrm{ml})$ of A.heterophyllus and A.altilis possessed significant antibacterial activity against Escherichia coli with $9.50 \pm 0.44 \mathrm{~mm}$ and $7.49 \pm 0.28$ $\mathrm{mm}$ inhibition zone radii respectively. Dichloromethane extracts of leaf and stem bark showed lesser antibacterial activity against both of the bacteria with inhibition zones of $3.00 \pm 0.34 \mathrm{~mm}$ to $5.66 \pm$ $0.16 \mathrm{~mm}$ while hexane extracts did not show any antibacterial activity. Antifungal activity on the other hand was not detected in any of the extracts. Bacterial antibiotic tetracycline and fungal antibiotic ketoconazole which were used as positive controls were more effective even at 1/10 concentration compared to all the plant extracts tested. Phytochemical screening confirmed the presence of phytosterols, anthraquinone, terpenoids, phenols, glycosides, flavonoids and diterpenes in both of the trees. These results confirm the potential antibacterial activity of A.heterophyllus and A.altilis

\footnotetext{
* Correspondence should be addressed to Dr. K.O.L.C. Karunanayake, Department of Botany, Faculty of Natural Sciences, The Open University of Sri Lanka, Nawala, Sri Lanka (Email: kokar@ou.ac.lk)
} 
stem barks and the presence of medicinally important phytochemicals in aerial parts of the plants.

$\begin{array}{ll}\text { Keywords: } & \text { Artocarpus heterophyllus, Artocarpus altilis, } \\ & \begin{array}{l}\text { Antimicrobial, Phytochemical, Plant extracts, } \\ \text { ethnomedicinal }\end{array}\end{array}$

\section{Introduction}

According to the World health organization (2012) the evolving public health threat of antimicrobial resistance is driven by both appropriate and inappropriate use of anti-infective medicines. Kumaraswamy et al. (2008) state that the biochemical molecules of plant origin appear to be a suitable alternative to overcome the problems caused by antibiotic resistant pathogens.

A wide range of plants express complex mixtures of secondary metabolites within each species (Arguedas \& Coley, 2005). Phenols, terpenoids, flavonoids, glycosides, tannins, alkaloids, steroids, saponins and resins are some important phytochemicals found in plants (Tiwari et al. 2011). An estimated 74\% of pharmacologically active plant derived components were discovered after following up on ethnomedicinal use. Thus, medicinal plants can be regarded as the richest bio-resource of drugs of modern medicine, folk medicine and chemical entities or templates for synthetic drugs (Joshual \& Takudzwa, 2013). Further, the discovery of medically important metabolites in common and abundant plants would minimize over exploitation of well known, rare medicinal plants.

Sri Lanka is recognized as a biodiversity hotspot as a great variety of flora and fauna inhabit the wide range of natural ecosystems found within the country (Pethiyagoda, 2005). In Sri Lanka, Artocarpus heterophyllus (Jack)and Artocarpus altilis (Dhel) fruits are a popular food among the locals. A.heterophyllus bark and fruit are medicinally used to treat sprains, fractures, diabetes and are also used for laxative effect of abdomen and to increase the breast milk production in nursing mothers (Fernando, 2003). Almost all the parts of A.heterophyllus and A.altilis are utilized to treat several infections and other ailments in the Caribbean islands, Polynesian islands, Taiwan, Malaya, Java, and Borneo (Deivanai and Bhore 2010; Jitendra et al. (2014). However, the usage of A.heterophyllus and A.altilis to treat infections has not been reported in Sri Lanka.

Satish et al. (2008) conducted an antimicrobial assay to test the efficacy of leaf extracts of 46 plants including A.heterophyllus 
against 14 pathogenic bacteria including E.coli. Aqueous extract of A.heterophyllys leaf didn't inhibit any of the test pathogens. Another study showed that the silver nanoparticles synthesized using an aqueous leaf extract of A.heterophyllus as a reducing agent, increased the inhibitory effect of six antibiotics against Salmonella paratyphi and Klebsiella pneumonia. In addition, it was reported that, among the 54 chemical components of the aqueous leaf extract, $37.4 \%$ were alcohols and $32.2 \%$ were carboxylic acids (Thirumurugan et al. 2010).

Kuete et al. (2011) tested the effectiveness of crude methanolic extract of Artocarpus communis (Synonym for A.altilis) stem bark and terpenoids and flavonoids isolated from the bark against selected bacteria and fungi. Lowest MIC value recorded for crude extract against E.coli was $64 \mu \mathrm{g} / \mathrm{ml}$. Lowest MIC value of $32 \mu \mathrm{g} / \mathrm{ml}$ was recorded for one flavonoid compound against P.aeruginosa which was more effective than the antibiotic chloramphenicol $(64 \mu \mathrm{g} / \mathrm{ml})$. Raman et al. (2012) and Mohanty and Pradhan (2014) reported that the methanolic and ethanolic leaf extracts of A.altilis were highly effective against some selected gram negative and gram positive bacteria including E.coli and M.luteus while the aqueous extracts (100 $\mathrm{mg} / \mathrm{ml}, 10 \mu 1$ per disc) were found to be the least effective.

Binumol \& Sajitha (2013) state that the methanolic extracts of A.heterophyllus bark and Artocarpus communis leaf and bark extracts showed effectiveness against Bacillus subtilis and Pseudomonas fluorescens while aqueous extracts did not show considerable activity against test organisms. Mbaeyi Nwaoha \& Onwuka (2014) investigated the antimicrobial properties and phytochemical composition of A.altilis leaf extracts using ethanol, $\mathrm{n}$ hexane and water. The ethanol extracts (at MIC $5 \mathrm{mg} / \mathrm{ml}$ ) were more effective against bacteria including E.coli and fungi including A.niger compared to the other solvents. $\mathrm{n}$ hexane extracts inhibited all the test organisms (at MIC $8 \mathrm{mg} / \mathrm{ml}$ ) while water extracts didn't inhibit any of the test organisms.

In addition to the antimicrobial activity of A.heterophyllus, anti inflammatory, anti oxidant, anti cholinergic, anti diabetic, immune modulatory effect, inhibition of protease, oestrogen regulation and inhibition of melanin biosynthesis have also been reported through several pharmacological research investigations of the plant parts (Jitendra et al. 2014). A.altilis has been found to exhibit antitubercular, antiplasmodial, antiatherogenic, antioxidant, antiausteric, antihypertensive, antihelmintic and skin lightening effects (Sikarwar et al. 2014). 
Although many studies have focused on the antibacterial activity of A.heterophyllus and A.altilis extracts, little attention has been given to antifungal activity. Further, while A.heterophyllus (Jak fruit) and A.altilis (Bread fruit) (Moraceae) are very common trees in Sri Lanka and popular as a source of food, their antimicrobial potential has not yet been locally utilized.

Therefore, the present study was conducted to examine the antifungal activity of $A$. heterophyllus and A.altilis in addition to its antibacterial activity, and to ascertain the phytochemical constitution of these two trees which are extensively grown throughout Sri Lanka.

\section{Methodology}

Aseptic techniques and universal lab safety protocols were followed throughout all experiments.

\section{Plant Collection}

Healthy fresh leaves and bark of both A.heterophyllus and A.altilis were collected from Colombo and Kalutara districts of Sri Lanka, cleaned, surface sterilized using $70 \%$ ethanol, washed with distilled water and allowed to shade dry for seven days at room temperature. Dried plant material was cut into small pieces and ground using an electric grinder (JENCONS-Osterizer) to obtain small sized material (approximately 2-4 $\mathrm{mm}$ in size) as reported by Karthy et al. (2009).

\section{Plant Extraction}

Extracts were prepared by maceration of the powdered samples $10 \mathrm{~g}$ each) in $100 \mathrm{ml}$ of $95 \%$ ethanol, 99\% dichloromethane or $99 \%$ hexane (A/R Grade) with intermittent shaking (mrc, TS-400 orbital shaker) for three days at room temperature. Extracts were filtered using Whatman grade 1 filter paper and were concentrated by rotary evaporator ( $\mathrm{IKA}^{\circledR} \mathrm{RV} 05$ basic) at $45^{\circ} \mathrm{C}$. Concentrated extracts were weighed to find the extraction efficiency on dry weight basis. All the twelve extracts were stored at $4^{\circ} \mathrm{C}$ until further use as described by Karthy et al. (2009).

Extraction efficiency was calculated as follows;

Extraction efficiency $\%=($ Final dry weight of extract $/$ Initial weight of dried plant material) x 100 (Shilpakar et al. 2011). 


\section{Microbial Cultures}

Escherichia coli, Micrococcus luteus and fungal strains Aspergillus niger and Trichoderma $s p$ were obtained as stock cultures from the Department of Botany, The Open University of Sri Lanka.Streaking of bacterial cultures was done and pure cultures were obtained from single colony isolation and were stored in Nutrient agar (NA) while pure cultures of fungi were obtained from a single spore isolate obtained from a spread plate. These were stored in Potato Dextrose Agar (PDA) and were stored at $4^{\circ} \mathrm{C}$ until further use (Kuete et al. 2011). Sub culturing of bacteria and fungi was done at two weeks intervals.

\section{Antimicrobial Assay}

Agar disc diffusion test was adopted to test the antimicrobial activity of extracts as described by Hasan et al. (2009). Stock solutions of extracts were prepared in $30 \mathrm{mg} / \mathrm{ml}$ concentration by dissolving dried plant extract in its respective extraction solvent. $3 \mathrm{mg} / \mathrm{ml}$ stock solutions of antibacterial antibiotic tetracycline and antifungal antibiotic ketoconazole were prepared using sterile distilled water and served as positive controls.

Sterile discs (Whatman grade 1 filter paper, each $6 \mathrm{~mm}$ diameter discs) were separately loaded with $50 \mu$ of plant extracts, positive control (Antibiotics Tetracycline against bacteria and Ketoconazole against fungi) and extraction solvents which served as negative control (95\% Ethanol, 99\% dichloromethane and 99\% hexane). All discs treated as above were left to dry overnight under sterile conditions and then placed in spread plates prepared from bacterial cell or fungal spore suspensions.

Bacterial cell suspensions were prepared from 24 hour cultures of bacteria by diluting a small amount of inocula in sterile distilled water. Turbidity was compared to match the 0.5 Mcfarland standard (approximately $1.5 \times 10^{8} \mathrm{cfu} / \mathrm{ml}$ ) ensuring that the cell concentration of the microbial suspension used to prepare each spread plate would be approximately $1.5 \times 10^{8} \mathrm{cfu} / \mathrm{ml}$ (Tiga, 2011).

Fungal spore suspensions were prepared by flooding 7 day old fungal culture plates with sterile distilled water dislodging the spores with a sterile glass rod and filtering through muslin cloth. Total number of fungal spores in the suspension was counted using a 
haemocytometer (NEUBAUER improved HBG) and was adjusted to 1 $\mathrm{x} 10^{6} \mathrm{spores} / \mathrm{ml}$ by diluting the suspension (Rana et al. 2011).

\section{Preparation of Culture Plates}

NA and PDA were used to culture bacteria and fungi respectively. Spread plates of the microorganisms were prepared using $100 \mu 1$ of microbial suspension prepared as indicated above. Discs treated as described above were transferred to the agar plates after the microbial suspension had been absorbed onto the agar. Plates were incubated at $37^{\circ} \mathrm{C}, 24 \mathrm{~h}$ and $25^{\circ} \mathrm{C}, 72 \mathrm{~h}$ for bacteria and fungi respectively. After the incubation period, radii of the clear zones were measured as described by Hasan et al. (2009). The Bio assay was repeated three times and mean values were obtained.

\section{Determination of MIC}

MIC was determined using the serial agar dilution method (Hasan et al. 2009). The extracts which showed good activity in the antimicrobial assay were selected to determine the MIC. Serial dilutions $(0.5,1,2$ and $3 \mathrm{mg} / \mathrm{ml})$ of each selected extract were prepared using sterile distilled water. Appropriate amounts of Nutrient broth $(5 \mathrm{ml})$ and selected 24 hours old standardized bacterial suspensions $(10 \mu \mathrm{l})$ were added to each of the extract dilutions and the whole set up was incubated at $37^{\circ} \mathrm{C}, 24 \mathrm{~h}$. The tube with the lowest concentration which showed no visible growth was considered as the MIC for that particular microbe.

\section{Statistical Analysis}

Results of the bio assay were represented as mean \pm SD of three replicates in each test. An analysis of variance (Two - way ANOVA) with type III sums of squares was performed using SPSS 20 software at $95 \%$ confidence interval.

\section{Phytochemical Screening}

Presence or absence of selected phytochemicals: phytosterols, anthraquinones, terpenoids, phenols, glycosides, flavanoids, diterpenes, tannins and alkaloids in each extract was determined by performing qualitative chemical tests as described by Tiwari et al. (2011), Shilpakar et al. (2011) and Sasidharan et al. (2011). 


\section{Results}

\section{Extraction Efficiency (on Dry Weight Basis)}

Extraction efficiency was higher in leaf extracts compared to the bark extracts except the hexane extract of A.heteophyllus in which bark extraction efficiency was higher than that of the leaf. Highest extraction efficiency of $22.88 \%$ was obtained in ethanolic leaf extract of A.heterophyllus whereas least extraction efficiency of $0.84 \%$ was obtained in ethanolic bark extract of A.altilis (Table 1).

Table 1. Percentage (\%) Extraction efficiency of A.heterophyllus and A. altilis leaf and stem bark by different extraction solvents (on dry weight basis)

\begin{tabular}{|c|c|c|c|}
\hline & 95\% Ethanol & $\begin{array}{c}\mathbf{9 9 \%} \\
\text { Dichloromethane }\end{array}$ & $\begin{array}{c}\mathbf{9 9 \%} \\
\text { Hexane }\end{array}$ \\
\hline A.heterophyllus & 22.88 & 12.17 & 5.29 \\
Leaf & 5.17 & 3.98 & 9.54 \\
Bark & 7.98 & 8.89 & 18.62 \\
\hline A.altilis & 0.84 & 8.30 & 15.04 \\
Leaf & \multicolumn{2}{|}{} \\
Bark & \multicolumn{2}{|}{} \\
\hline
\end{tabular}

\section{Antimicrobial Assay}

Highest inhibition zone radius of $9.50 \pm 0.44 \mathrm{~mm}$ was found in the ethanol extract of A.heterophyllus bark against E.coli followed by the ethanolic extract of A.altilis bark $(7.49 \pm 0.28 \mathrm{~mm})$ against E.coli. Dichloromethane extracts showed moderate activity against test bacteria, the exception being the dichloromethane leaf extract of A.heterophyllus against M.luteus where no inhibition was noted. None of the hexane extracts of both trees showed any activity against tested bacteria. Tetracycline was generally more effective (except ethanolic extract of $A$. altilis bark against $E$. coli) against both E.coli and M.luteus than the plant extracts even at $1 / 10^{\text {th }}$ concentration (Table 2). 
Table 2. Mean inhibition zone radius $\pm S D$ in $m m$ of A.heterophyllus and A.altilis leaf and stem bark extracts against E.coli and M.luteus

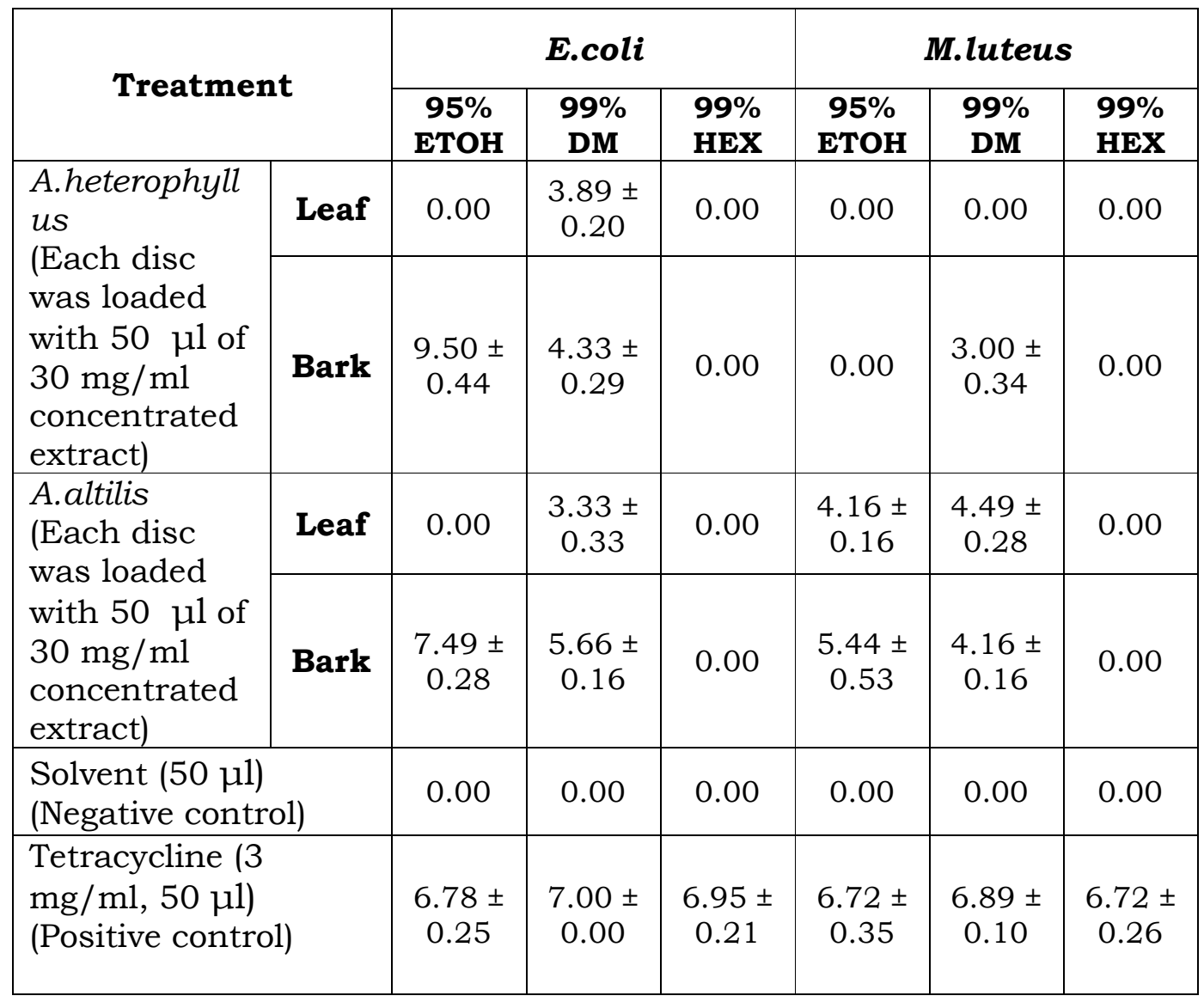

ETOH $=$ Ethanol, $\mathrm{DM}=$ Dichloromethane, HEX $=$ Hexane, $\mathrm{SD}=$ Standard deviation

None of the extracts of A.heterophyllus and A.altilis showed any antifungal activity against A.niger or Trichoderma sp. Antifungal antibiotic ketoconazole was effective against both of the fungi, while negative control solvents did not inhibit fungi.

\section{Minimum Inhibitory Concentration (MIC)}

The four extracts which showed the highest inhibition zone radius in the disc diffusion test were selected for the MIC determination test. Ethanolic bark extracts of A.heterophyllus and A.altilis inhibited E.coli in all concentrations tested. Dichloromethane bark extract of A.altilis inhibited E.coli in $2 \mathrm{mg} / \mathrm{ml}$ and $3 \mathrm{mg} / \mathrm{ml}$ concentrations. 
Ethanolic bark extract of A.altilis inhibited M.luteus in all concentrations except $0.5 \mathrm{mg} / \mathrm{ml}$ (Table 3).

Table 3. Presence or absence of visible microbial growth in treatment tubes as an indication of the MIC of selected extracts

\begin{tabular}{|l|c|c|c|c|}
\hline \multicolumn{1}{|c|}{$\begin{array}{c}\text { Concentrations } \\
\text { Extracts }\end{array}$} & $\begin{array}{c}\mathbf{0 . 5} \\
\mathbf{m g} / \mathbf{m l}\end{array}$ & $\begin{array}{c}\mathbf{1} \\
\mathbf{m g} / \mathbf{m l}\end{array}$ & $\begin{array}{c}\mathbf{2} \\
\mathbf{m g} / \mathbf{m l}\end{array}$ & $\begin{array}{c}\mathbf{3} \\
\mathbf{m g} / \mathbf{m l}\end{array}$ \\
\hline $\begin{array}{l}\text { Ethanol - A.heterophyllus } \\
\text { bark against E.coli }\end{array}$ & --- & - & - & - \\
\hline $\begin{array}{l}\text { Ethanol - A.altils bark } \\
\text { against E.coli }\end{array}$ & ---- & - & - & - \\
\hline $\begin{array}{l}\text { Dichloromethane - A.altils } \\
\text { bark against E.coli }\end{array}$ & + & + & --- & - \\
\hline $\begin{array}{l}\text { Ethanol - A.altils bark } \\
\text { against M.luteus }\end{array}$ & + & --- & - & - \\
\hline $\begin{array}{l}\text { Positive control - } \\
\text { Tetracycline }\end{array}$ & --- & - & - & - \\
\hline
\end{tabular}

(-) - Growth absent, (+) - Growth present, (----) - Growth absent (Minimum inhibitory concentration of particular extract according to tested concentrations in present study)

\section{Phytochemical Analysis}

All the extracts of A.heterophyllus showed the presence of phytosterols and terpenoids. Anthraquinone was present in all the bark extracts. Flavonoids were present only in ethanolic extracts of leaves and bark. Phenols and glycosides were present only in ethanolic leaf extract and ethanol and dichloromethane extracts of bark. Diterpenes were present only in ethanolic leaf extract while tannins and alkaloids were absent in all the extracts of A.heterophyllus (Table 4).

In A.altilis all the bark extracts and ethanolic leaf extract showed the presence of phytosterols. Anthraquinone was present in all the leaf extracts and absent in bark extracts. Terpenoids were present in hexane extracts of leaves and bark and dichloromethane extract of leaf. Phenols were present only in ethanol and dichloromethane extracts of leaves. Flavonoids and diterpenes were present only in ethanolic extracts of leaves and bark. Glycosides were present in 
ethanolic leaf and bark extract and dichloromethane leaf extract. Tannins and alkaloids were absent in all the extracts (Table 4).

Table 4. Phytochemical screening of A.heterophyllus and A.altilis leaves and stem bark extracted using different solvents

\begin{tabular}{|c|c|c|c|c|c|c|c|c|c|c|c|c|}
\hline \multirow{3}{*}{$\begin{array}{l}\text { Treatment } \\
\text { Phytochemi } \\
\text { cals }\end{array}$} & \multicolumn{6}{|c|}{ Leaves } & \multicolumn{6}{|c|}{ Barks } \\
\hline & \multicolumn{2}{|c|}{$\begin{array}{c}\text { 95\% } \\
\text { ETOH }\end{array}$} & \multicolumn{2}{|c|}{$\begin{array}{l}99 \% \\
\text { DM }\end{array}$} & \multicolumn{2}{|c|}{$\begin{array}{l}99 \% \\
\text { HEX }\end{array}$} & \multicolumn{2}{|c|}{$\begin{array}{c}\text { 95\% } \\
\text { ETOH }\end{array}$} & \multicolumn{2}{|c|}{$\begin{array}{l}99 \% \\
\text { DM }\end{array}$} & \multicolumn{2}{|c|}{$\begin{array}{l}\text { 99\% } \\
\text { HEX }\end{array}$} \\
\hline & $\begin{array}{c}\text { A. } \\
\text { h. }\end{array}$ & $\begin{array}{c}\text { A. } \\
\text { a }\end{array}$ & $\begin{array}{c}\text { A. } \\
\text { h. }\end{array}$ & $\begin{array}{r}\text { A. } \\
\text { a }\end{array}$ & $\begin{array}{c}\text { A. } \\
\text { h }\end{array}$ & $\begin{array}{c}\text { A. } \\
\text { a }\end{array}$ & $\begin{array}{c}\text { A. } \\
\text { h. }\end{array}$ & $\begin{array}{c}\text { A. } \\
\text { a }\end{array}$ & $\begin{array}{l}\text { A. } \\
h\end{array}$ & $\begin{array}{c}\text { A. } \\
\text { a }\end{array}$ & $\begin{array}{c}\text { A. } \\
\text { h }\end{array}$ & $\begin{array}{l}\text { A. } \\
\text { a }\end{array}$ \\
\hline Phytosterols & + & + & + & - & + & - & + & + & + & + & + & + \\
\hline $\begin{array}{l}\text { Anthraquino } \\
\text { ne }\end{array}$ & - & + & - & + & - & + & + & - & + & - & + & - \\
\hline Terpenoids & + & - & + & + & + & + & + & - & + & - & + & + \\
\hline Phenols & + & + & - & + & - & - & + & - & + & - & - & - \\
\hline Glycosides & + & + & - & + & - & - & + & + & + & - & - & - \\
\hline Flavonoids & + & + & - & - & - & - & + & + & - & - & - & - \\
\hline Diterpenes & + & + & - & - & - & - & - & + & - & - & - & - \\
\hline Tannins & - & - & - & - & - & - & - & - & - & - & - & - \\
\hline Alkaloids & - & - & - & - & - & - & - & - & - & - & - & - \\
\hline
\end{tabular}

A.h - A.heterophylus, A.a-A.altilis, (+) - Present, (-) - Absent, ETOH - Ethanol, DM - Dichloromethane, HEX - Hexane

\section{Discussion}

Extraction efficiency was high in leaf extracts compared to bark extracts except in A.heterophyllus hexane extracts, in which the extraction efficiency of bark was $9.54 \%$ and leaf was only $5.29 \%$ (Table 1). Leaves are thinner and less complex than the bark. Therefore, compared to bark extraction, solvents could penetrate more easily and dissolve more of the phytochemicals in leaves. The highest extraction efficiency was found in the ethanolic extract of A.heterophyllus leaf (22.88\%) (Table 1). Franco et al. (2008) report that ethanol is preferred by many researchers since it poses less toxicity and higher extraction yield. Rahmoun et al. (2014) state that extraction yield increases with the increasing polarity of the solvent which is in agreement with the present results. 
Although investigations on antimicrobial activity of A.heterophyllus and A.altilis aqueous extracts were carried out by Binumol \& Sajitha (2013), Mbaeyi Nwaoha \& Onwuka, (2014), Raman et al. (2012) and Satish et al. (2008), none of the reports recommended the use of water as an extraction solvent as little or no antimicrobial activity was seen in any of the investigations. Since the literature available up to date reiterate about very little or no antimicrobial activity of aqueous extracts of both the plants, using distilled water as an extraction solvent and thereby investigating the antimicrobial potential of aqueous extracts were omitted in the present study even though working with the aqueous extracts is less expensive and more environmentally friendly than the use of other extraction solvents.

Both A.heterophyllus and A.alilis bark showed significant antimicrobial activity against the gram negative bacterium tested. Ethanolic bark extracts of A.heterophyllus $(9.50 \pm 0.44 \mathrm{~mm})$ and A.altilis $(7.49 \pm 0.28 \mathrm{~mm})$ strongly exerted significant antimicrobial activity against E.coli which is a gram negative bacterium. But ethanolic leaf extracts of both plants failed to inhibit E.coli (Table 2). Similar finding related to bark extract has been reported by Kuete et al. (2011) and Binumol \& Sajitha (2013), in which methanolic extract of Artocarpus communis (now known as A.altilis) stem bark and some isolated compounds (Terpenoids and Flavonoids) were effective against E.coli and methanolic bark extracts of both plants were effective against P.fluorescens (gram negative) and B.subtilis (gram positive) respectively. Efficient extraction by high polar ethanol and presence of bio active phytochemicals in the stem bark being stated as the reasons for this notable higher antimicrobial activity.

Contrary to the present findings, Raman et al. (2012), Mbaeyi Nwaoha \& Onwuka, (2014) and Binumol \& Sajitha (2013) reported the antimicrobial activity of A.heterophyllus and A.altilis methanolic and ethanolic leaf extracts against certain gram positive and gram negative bacteria including E.coli. This difference between literature and the present study regardless of the phytochemistry of leaf extracts, may be due to the result of inadequate usage of extracts in the bioassay $(\approx 1.5 \mathrm{mg} /$ disc $)$.

Among all the extracts tested, only the dichloromethane bark extract of A.heterophyllus was effective against M.luteus. However in A.altilis, ethanol and dichloromethane leaf and bark extracts showed considerable activity against M.luteus (Table 2). Similar findings have been reported by Raman et al. (2012). All the dichloromethane 
extracts except A.heterophyllus leaf extract have inhibited E.coli and M.luteus at a considerable level (Table 2). Omar et al., 2013 reported that stigmasterol isolated from the dichloromethane twig extract of A.altilis was effective against S.aureus. Leaf extracts of A.altilis obtained using some other medium polar solvents such as chloroform and ethyl acetate have also shown good antimicrobial activity against bacteria including E.coli and M.luteus (Mohanty \& Pradhan, 2014; Raman et al. 2012). As such it seems probable that the medium polar solvents effectively extract bioactive phytochemicals.

All the n-hexane extracts $(\approx 1.5 \mathrm{mg} /$ disc $)$ of both of the plants did not show any antimicrobial activity against E.coli or M.luteus (Table 2). Results indicate that, hexane is significantly ineffective compared to the other medium and high polar extraction solvents in extracting bioactive compounds. It appears that hexane failed to extract bioactive phytochemicals although hexane showed good extraction efficiency (Table 1). However, one report by Mbaeyi Nwaoha \& Onwuka (2014) state that $\mathrm{n}$ hexane extract of A.altilis leaf inhibited E.coli and further Omar et al. (2013) stated cycloartenyl acetate isolated from hexane twig extract of A.altilis inhibited S.aureus. So it is possible that higher concentrations of crude hexane extracts could inhibit bacteria.

None of the extracts showed antifungal activity against A.niger and Trichoderma $\mathrm{sp}$ at the concentrations tested in the present study. Mbaeyi Nwaoha \& Onwuka (2014) reported that ethanolic leaf extract of A.altilis inhibited A.niger at $6 \mathrm{mg} / \mathrm{ml}$ MIC while $\mathrm{n}$ hexane inhibited at $8 \mathrm{mg} / \mathrm{ml}$ MIC. Kuete et al. (2011) and Raman et al. (2012) found that methanolic and ethanolic leaf extracts of A.altilis were effective against Candida sp and Mucor sp. The reason behind the absence of antifungal activity may be due to inefficient extraction of antifungal phytochemicals or inadequate dosage of the extracts. Since all the replicates showed no antifungal activity and only one publication (Mbaeyi Nwaoha \& Onwuka (2014) states antifungal activity of A.altilis leaves at higher dosage (MIC of ethanolic extract was $5 \mathrm{mg} / \mathrm{ml}$ and MIC of $\mathrm{n}$ hexane extract was $8 \mathrm{mg} / \mathrm{ml}$ against $A$,niger), it is not possible to conclude on the antifungal activity of A.heterophyllus and A.altilis.

Antibiotics tetracycline and ketoconazole $(\approx 0.15 \mathrm{mg} / \mathrm{disc})$ were more effective than any of the tested plant extracts against bacteria and fungi respectively. Use of an equal amount of antibiotics as plant extracts resulted in very large zones of inhibition in the very first trial of this present study. As the main objective of this study 
was to investigate and compare the antimicrobial activity of A.heterophyllus and A.altilis trees, the concentration of antibiotics was reduced to $1 / 10^{\text {th }}$ of the concentration of plant extracts and considered only as a positive control. This reduction in concentration further provided the plant extracts sufficient space to show their inhibitory effect.

Kuete et al. (2011) reported that the phytochemicals are classified as antimicrobials on the basis of MIC in the range of $100-1000 \mathrm{mg} / \mathrm{ml}$. According to Rios \& Recio (2005) quantities lower than $1 \mathrm{mg} / \mathrm{ml}$ for extracts and quantities lower than $0.1 \mathrm{mg} / \mathrm{ml}$ for isolated compounds are considered noteworthy. In the present study ethanolic bark extracts of A.heterophyllus and A.altilis inhibited E.coli at MIC $0.5 \mathrm{mg} / \mathrm{ml}$ (Table 4). Kuete et al. (2011) reported that the lowest MIC of methanolic bark extract of A.communis against E.coli was $64 \mu \mathrm{g} / \mathrm{ml}$.

According to Mbaeyi Nwaoha \& Onwuka (2014) ethanolic leaf extract of A.altilis showed inhibition of E.coli and A.niger at MIC $6 \mathrm{mg} / \mathrm{ml}$. This further supports the statement that, stem barks of A.heterophyllus and A.altilis (MIC at $0.5-1 \mathrm{mg} / \mathrm{ml}$, Table 3) are more effective than leaves.

Previous reports on phytochemical screening of A.heterophyllus leaf showed the presence of flavanoids, terpenoids, steroids, phenols, glycosides and saponins while stem bark showed all the above stated phytochemicals and in addition alkaloids and tannins. Meanwhile A.altilis leaves showed the presence of alkaloids, flavanoids, glycosides, steroids, saponins, tannins, and stem barks showed the presence of flavanoids, glycosides, terpenoids, tannins, steroids and anthraquinones (Binumol \& Sajitha, 2013; Kute et al. 2011; Mbaeyi Nwaoha \& Onwuka, 2014; Raaman et al. 2014; Raman et al. 2012).

When comparing the plants A.heterophyllus and A.altilis, all the tested phytochemicals were present in both of the plants. But interestingly anthraquinones were present only in A.heterophyllus bark but in A.altilis those were present only in the leaves. Further, the present results are in agreement with the findings of Mohanty \& Pradhan (2014) and Amponsah et al. (2014) hence proves the phytochemical diversity of secondary metabolites in both of the tested plants.

Although the presence of tannins and alkaloids have been reported in both of the plants (Amponsah et al. 2014; Binumol \& Sajitha, 2013; Elevitch \& Manner, 2006; Mbaeyi Nwaoha \& Onwuka, 2014; 
Mohanty \& Pradhan, 2013; Raman et al. 2012) tests for tannin and alkaloids gave negative results in all the extracts in the present study (Table 4).

\section{Conclusion}

Results of the present in vitro antimicrobial assay and MIC test revealed the antibacterial potentiality of stem barks of A.heterophyllus and A.altilis which reiterate the broad spectrum of antibacterial activity of both of the plant extracts against gram negative and gram positive bacteria. The most effective of the extraction solvents proved to be ethanol, followed by dichloromethane, and hexane was found to be the least effective of the tested solvents. The antimicrobial activity of extracts was further supported by the presence of phenols, terpenoids, flavonoids, anthraquinone, phytosterols, glycosides and diterpenes in the extracts which are known to possess antimicrobial properties. Therefore, the present investigation draws attention to the phytochemistry and the antimicrobial properties of both A.heterophyllus and A.altilis by providing supportive data to indicate that the isolation, characterization and ethnomedicinal in vivo investigations of phytochemicals from A.heterophylus and A.altilis could act as a platform to formulate promising antimicrobials against pathogens.

\section{References}

Amponsah, I. K., Annan, K., Koffuor, G. A., Sarkodie, J. A., Umerie, I. J., \& Osei wusu, S. (2014). Anti-inflammatory and antioxidant properties of the ethanolic stem bark extract of Artocarpus altilis (Parkinson) Fosberg (Moraceae). Der Pharmacia Lettre, 6(3), 211-217.

Arguedas, T. B., \& Coley, P. D. (2005). Phenotypic variation and spatial structure of secondary chemistry in a natural population of a tropical tree species. OIKOS, 108, 410-420.

Binumol, M. \& Sajitha, T. (2013). Phytochemical and antibacterial activity of Artocarpus heterophyllus Lam. and Artocarpus communis Forst. on Bacillus subtilis and Pseudomonas fluorescens. International Journal of Scientific \& Engineering Research, 4, 1766-1784. 
Deivanai, S., \& Bhore, S. J. (2010). Bread fruit (Artocarpus altilis Fosb.) - An underutilized and neglected fruit plant species. Middle East journal of Scientific research, 6(5), 418-428.

Elevitch, C. R. \& Manner, H. I. (2006). Artocarpus heterophyllus (Jackfruit). Retrieved from https://retirenicaragua.files.wordpress.com/2012/05/aheterophyllus-jackfruit1.pdf (Accessed 26 on Nov.2014).

Fernando, S. (2003). Herbal food and medicines in Sri Lanka. New Delhi. (Original work published in 1982).

Franco, D., Sineiro, J., Rubilar, M., Sanchez, M., Jerez, M., Pinel, M., Nunez, M. J. (2008). Polyphenols from plant materials: extraction and antioxidant power. Electronic journal of environmental, agricultural and food Chemistry, 7(8), 32103216.

Hasan, M. F., Das, R., Khan, A., Hossain, M. S., \& Rahman, M. (2009). The Determination of Antibacterial and Antifungal Activities of Polygonum hydropiper (L.) Root Extract. Advances in Biological Research, 3, 53-56.

Jitendra, R., Kalpana, S., Shweta, S., Kumar, M. S., \& Manish, B. (2014). Artocarpus heterophyllus (jackfruit) potential unexplored in dentistry- an overview. Universal journal of Pharmacy, 3(1), 50-55.

Joshual, M. \& Takudzwa, M. (2013). Antibacterial properties of Mangifera indica on Staphylococcus aureus. African journal of clinical and experimental microbiology, 14, 62-74.

Karthy, E. S., Ranjitha, P., Mohankumar, A. (2009). Antimicrobial potential of plant seed extracts against multidrug resistant methicillin resistant Staphylococcus aureus (MDR-MRSA). International Journal of Biology, 1, 34-40.

Kuete, V., Ango, P. Y., Fotso, G. W., Kapche, G. D. W. F., Dzoyem, J. P., Wouking, \& Abeghas, B. M. (2011). Antimicrobial activities of the methanolic extract and compounds from Artocarpus communis (Moraceae). BMC Complementary and Alternative Medicine, 11, 1-5.

Kumaraswamy, M. V., Kavitha, H. U., \& Satish, S. (2008). antibacterial evaluation and phytochemical analysis of Betula 
utilis D. Don against some human pathogenic bacteria. World Journal of Agricultural Sciences, 4(5), 661-664.

Nwaoha, I. E. M., \& Onwuka, C. P. (2014). Comparative evaluation of antimicrobial properties and phytochemical composition of A.altilis leaves using ethanol, $\mathrm{n}$ hexane and water. African journal of Microbiology research, 8(37), 3409-3421.

Mohanty, M. \& Pradhan, C. (2014). Phytoconstituent analysis and comparative bioefficacy assessment of breadfruit fruit and leaf extracts for antipathogenic potentiality. American journal of phytomedicine and clinical therapeutics, 2(1), 77-87.

Omar, M. N., Muzammil, A., Khan, N. T., Zahid, M. \& Kamal, T. (2013). Isolation and identification of bioactive compounds from twigs of Artocarpus altilis. Merit Research Journal of Environmental Science and Toxicology, 1, 147-155.

Pethiyagoda, R. (2005). Exploring Sri Lanka's biodiversity. The raffles bulletin of Zoology, 12, 1-4.

Rahmoun, N. M., Ziane, H. \& Boucherit Otmani, Z. (2014). Antibacterial and antifungal screening of four medicinal plants. Journal of Coastal Life Medicine, 2(12), 975-979.

Raaman, N., Sivaraj, C. \& Tenzing. (2014). Antioxidant activites and phytochemical analysis of methanol extract of leaves of Artocarpus heterophyllus Lam. International Journal of Pharmacy and Pharmaceutical Sciences, 6, 289-293.

Raman, V., Sudhahar, D. \& Anandarajagopal, K. (2012). Preliminary phytochemical investigation and screening of antimicrobial activity of leaf extracts of Artocarpus altilis. Asian journal of Biological and Life Sciences, 1(2), 104-107.

Rana, I. S., Rana, A. S. \& Rajak, R. C. (2011). Evaluation of antifungal activity in essential oil of the Syzygium aromaticum (L.) by extraction, purification and analysis of its main component eugenol. Brazilian Journal of Microbiology, 42, 1269-1277.

Rios, J. L. \& Recio, M. C. (2005). Medicinal plants and antimicrobial activity. Journal of Ethnopharmacology, 100, 80-84. 
Sasidharan, S., Chen, Y., Saravanan, D., Sundram, K. M. \& Yoga Latha, L. (2011). Extraction, isolation and characterization of bioactive compounds from plants' extracts. African Journal of Traditional, Complementary and Alternative medicines, 8, 1.

Satish, S., Raghavendra, M. P. \& Raveesha, K. A. (2008). Evaluation of the antimicrobial potential of some plants against human pathogenic bacteria. Advances in Biological Research, 2, 44.

Shilpakar, A., Gaire, B. P., Sunar, C. B., Lamichhane, R. \& Neupane, S. (2009). Phytochemical screening and analysis of antibacterial and antioxidant activity of Ficus auriculata, Lour. stem bark. (Bachelor's thesis). Retrieved from http://www.researchgate.net/profile/Bhakta_Gaire/publicati on /221677460Phytochemical_screening_and_analysis_of_anti bacterial_and_antioxidant_activity_of_Ficus_auriculata_\%28L our.\%29_Stem_Bark/links/0922b4f5ed8b5bf060000000 Accessed on 25 Nov. 2014).

Sikarwar, S. M., Hui, B, J., Subramaniam, K., Valeisamy, B., Yean, L. K. \& Balaji, K. (2014). A Review on Artocarpus altilis (Parkinson) Fosberg (breadfruit). Journal of Applied Pharmaceutical Science, 4 (08), 091-097.

Thirumurugan, A., Tomy, N. A., Jai ganesh, R. \& Gobikrishnan, S. (2010). Biological reduction of silver nanoparticles using plant leaf extracts and its effect on increased antimicrobial activity against clinically isolated organism. Der Pharma Chemica, 2, 279-284.

Tiga, S. (2011). Characterization and identification of some medically important bacterial isolates. (Master's dissertation). Retrieved, http://ethesis.nitrkl.ac.in/2435/1/Suman_Thesis_final.pdf. (Accessed on 12 Nov. 2014).

Tiwari, P., Kumar, B., Kaur, M., Kaur, G. \& Kaur, H. (2011). Phytochemical screening and Extraction: A Review. International Pharmaceutica Sciencia, 1, 98-106.

World health organization. (2012). The evolving threat of antimicrobial resistance options for action. Retrieved from http://whqlibdoc.who.int/publications/2012/978924150318 1_eng.pdf (Accessed 29 on Nov.2014).

Received: 30-4-2015 Revised: 6-8-2015 Accepted: 7-9-2015 
